\title{
A Comparative Study of Physico-Chemical and Cooking Qualities of Rice
}

\author{
Priti P. Lad ${ }^{1 *}$, Rakesh T. Gangurde ${ }^{1}$, Pankaj J. Jadhav ${ }^{1}$, \\ Samadhan L. Gavade ${ }^{1}$ and Nitesh A. Pachpor ${ }^{2}$ \\ ${ }^{1}$ Department of Agriculture Process Engineering, ${ }^{2}$ Department of Renewable Energy \\ Technology, College of Agriculture Engineering and Technology, Saralgaon, India
}

*Corresponding author

\begin{tabular}{|l|}
\hline Ke y w o r d s \\
Indrayani rice, \\
1008 rice variety, \\
Physic-chemical \\
properties, Cooking \\
qualities
\end{tabular}

Keywords

Indrayani rice, 1008 rice variety, Physic-chemical properties, Cooking Article Info

Accepted: Available Online: 10 December 2018

\section{A B S T R A C T}

The present study aimed to compare the physico-chemical properties of rice. The physical properties of rice are important tool for designing agricultural machines and other equipments to handle planting, harvesting, processing, packaging and storing. The physical parameters such as length, width, thickness, surface area, bulk and true density, sphericity, porosity, aspect ratio, etc. are determined. The Indrayani rice is long in length $6.05 \mathrm{~mm}$ where the 1008 is short $5.3 \mathrm{~mm}$. The average width and thickness of Indrayani is $1.92 \mathrm{~mm}$ and $1.43 \mathrm{~mm}$ respectively. The sphericity and aspect ratio is 0.41 and $0.31 \%$ respectively. The Bulk density and True density is 0.92 and 1.31 respectively. Also the porosity is 29.55 per cent, 1000 kernel weight is $16.05 \mathrm{gm}$. The angle of repose is 32.59 degree. In case of 1008 rice variety the width is $1.81 \mathrm{~mm}$, thickness is $0.91 \mathrm{~mm}$, equivalent diameter is 2.15 $\mathrm{mm}$, sphericity is 0.32 , and aspect ratio is 0.32 respectively. The chemical properties such as crude fibre, Ash, Protein, Carbohydrates, Energy value and Fat are calculated. We observe that, protein content in Indrayani and 1008 is 8.44 and 8.31 per cent respectively. Energy value per 100 gram of sample is 362 and $400 \mathrm{kcal}$ for Indrayani and 1008 respectively. The carbohydrates in rice are 80.5 percent in Indrayani and 82.1 percent in 1008. The fat content is 0.66 per cent in Indrayani and $0.6 \%$ in 1008. In cooking characteristics the cooking time, grain elongation, and water uptake ratio is studied. The Indrayani has 3.51 water uptake ratio, 1.12 grain elongation ratio and $11.36 \pm 2 \mathrm{~min}$ cooking time. The 1008 rice has 3.18 water uptake ratio, 1.18 elongation ratio and $9.61 \pm 2$ min cooking time.

\section{Introduction}

Rice (Oryza sativa L.) is the staple food for more than half of the world's population. About $90 \%$ of the world's rice is grown and consumed in Asia (Tyagi et al., 2004). Rice is ranked as the world's number one human food crop (Itani et al., 2002) and an economically important food crop with nutritional diversification that helps in poverty alleviation (Otegbayo et al., 2001). Rice is mainly consumed in whole milled form. Rice milling is a combination of several unit operations to convert paddy into well-milled silky-white rice, which has superior cooking quality attributes. Grain quality of rice is determined 
by several factors such as grain appearance, nutritional value, cooking and eating quality. Rice is consumed principally as a whole grain and the texture of the whole grain is a matter of great concern. Rice quality is of great importance for all people involved in producing, processing and consuming rice, because it affects the nutritional and commercial value of grains.

Grain quality is based upon objective and subjective criteria, the relative importance of which depends upon the particular end-use. The most important quality components, common to all users, include appearance, milling, cooking, processing and nutritional quality. Further grain quality has become an important issue affecting domestic consumption and international trade of rice (Lodh, 2002). The physico-chemical characteristics include grain length, breadth, $\mathrm{L} / \mathrm{B}$ ratio, hulling and milling percentage. Grain quality is a very wide area encompassing diverse characters that are directly or indirectly related to exhibit one quality type.

\section{Materials and Methods}

\section{Raw material}

Two varieties of rice samples Indrayani and 1008 were selected for analysis. The two varieties were obtained from the local market of Wadivarhe (Nashik). The primary objective of the study which was to investigate the differences in physico-chemical properties and cooking qualities of two rice varieties.

\section{Physical properties}

\section{Grain dimensions}

Grain Dimensions were determined using general vernier caliper. Twenty grains from each sample were collected at random and the dimensions were measured to obtain the average length, width and thickness of the selected rice (Indrayani and 1008).

\section{Grain shape}

Based on the length to width ratio $(\mathrm{L} / \mathrm{w})$, the shape of the milled rice was determined (IR.RI, 2004). L/w ratio is calculated as follows:

$$
\mathrm{L} / \mathrm{W}=\frac{\text { Average length of rice }}{\text { Average width of rice }} \quad 1
$$

\section{Equivalent diameter (De)}

The equivalent diameter considering a prolate spheroid shape for a Indrayani rice and 1008 rice were determined by using expression as described under (Mir et al., 2013).

$$
D e=\left(L \frac{(W+T)^{\mathrm{z}}}{4}\right)^{1 / 3} \ldots \ldots \ldots 2
$$

Where,

L: Length of rice grain

$\mathrm{W}$ : Width Of rice grain

T: Thickness Of rice grain

\section{Sphericity (Ø)}

The ratio of the surface area of the sphere having the same volume as that of grain to the surface area of the grain was determined using expression as described by (Mir et al., 2013).

$$
\emptyset=\frac{(L W T)^{1 / / s}}{L}
$$

Where,

L: Length of rice grain

$\mathrm{W}$ : Width of rice grain

$\mathrm{T}$ : Thickness of rice grain

\section{Grain volume (V)}

Grain volume (V) of Indrayani and 1008 rice were calculated by using different expressions (Mir et al., 2013). 


$$
\begin{aligned}
& V=0.25\left[\left(\frac{\pi}{6}\right) L(W+T)^{2}\right] \ldots \ldots \ldots 4 \\
& B=\sqrt{W T}
\end{aligned}
$$

Where,

L: Length of rice grain

W: Width of rice grain

T: Thickness of rice grain

\section{Aspect ratio (Ra)}

It is the ratio of width and the length of the grain determined by using following formulae (Mir et al., 2013).

$$
R a=\frac{W}{L}
$$

Where,

$\mathrm{T}$ : Thickness Of rice grain

$\mathrm{W}$ : Width Of rice grain

\section{0 grain weight}

1000 grains of the sample were counted and weighted with the help of weighing balance (Verma et al., 2015)

\section{Bulk and true density}

The bulk density $(\rho b)$ was determined by using the mass/volume relationship by filling an empty plastic container of predetermined volume and tare weight with the grains by pouring from a constant height, striking off the top level and weighing. The true density $(\rho t)$ was determined by the toluene displacement (Mohsenin, 1986).

\section{Porosity}

Porosity $(\varepsilon)$ was defined as the ratio of intergranular void space volume and the volume of the bulk grain.

Porosity was computed using an expression as described (Mir et al., 2013).
Porosity $=\frac{\text { True Density }- \text { Bulk Density }}{\text { True Density }}$....6

\section{Angle of repose}

The angle of repose $\left(\theta_{\mathrm{f}}\right)$ was determined by using an empty cylindrical mold of $15 \mathrm{~mm}$ diameter and $25 \mathrm{~mm}$ height. The cylinder was placed at the centre of galvanized iron plate, filled with rice grains and raised gradually until it forms a cone of grain. The height of the cone was measured and the filling angle of repose was calculated by the following relationship (Mir et al., 2013).

$$
\theta \mathrm{f}=\tan ^{-1} \frac{2 H}{D}
$$

Where,

$\mathrm{H}$ : height

D: diameter of cone respectively.

\section{Chemical properties}

\section{Determination of moisture content}

Moisture was determined by Standard Official Methods of Analysis of the AOAC. This involved drying to a constant weight at $100 \mathrm{OC}$ and calculating moisture as the loss in weight of the dried rice samples. The crucible was thoroughly washed and dried in an oven at 100 ${ }^{0} \mathrm{C}$ for $30 \mathrm{~min}$ and allowed to cool inside desiccators. After cooling, they were weighed using weighing balance and their various weights recorded as (W1). Then, $2.0 \mathrm{~g}$ of the finely ground rice samples were put into the crucibles and weighed to get W2. Thereafter, the sample plus crucible were placed inside the oven and dried at $100{ }^{\circ} \mathrm{C}$ for 4 hours, cooled and weighed at the same temperature for $30 \mathrm{~min}$ until constant weights were obtained to get W3. Then, the moisture content of the rice sample was calculated from the equation:

$\%$ Moisture $=(\mathrm{W} 2-\mathrm{W} 3) /(\mathrm{W} 2-\mathrm{W} 1) \times 100$ .8 
Where W1= Initial weight of empty crucible $\mathrm{W} 2=$ weight of crucible + sample before drying and $\mathrm{W} 3=$ Final weight of crucible + sample after drying.

\section{Determination of ash}

Total ash of the rice sample was determined by Furnace Incineration described by AOAC[10] (method 14:006) based on the vaporization of water and volatiles with burning organic substances in the presence of oxygen in the air to $\mathrm{CO}_{2}$ at a temperature of $600{ }^{0} \mathrm{C}$ (dry ashing). About $1.0 \mathrm{~g}$ of finely ground dried sample was weighed into a 277 tared porcelain crucible and incinerated at 600 ${ }^{0} \mathrm{C}$ for $6 \mathrm{hr}$ in an ashing muffle furnace (Model 1184A Fisher Scientific, Houston, TX) until ash was obtained. The ash was cooled in a dessicator and reweighed. The \% ash content in the rice sample was calculated as:

\section{\% Ash}

$$
=\frac{\text { weight of Ash }}{\text { weight if original sample }} \times 100
$$

\section{Determination of crude fibre}

Crude fibre was determined using the method of AOAC. About $2.0 \mathrm{~g}$ of the rice sample was hydrolyzed in a beaker with petroleum ether after which it was boiled under reflex for 30 min with $200 \mathrm{ml}$ of a solution containing $1.25 \% \mathrm{H}_{2} \mathrm{SO}_{4}$ per $100 \mathrm{ml}$ of solution. The solution was filtered through a filter paper onto a fluted funnel. After filtration, the samples were washed with boiled water until they were no longer acidic. Then, the residue was transferred onto a beaker and boiled for another $30 \mathrm{~min}$ with $200 \mathrm{ml}$ of solution containing $1.25 \% \mathrm{NaOH}$ per $100 \mathrm{ml}$. The boiled samples were washed with boiled distilled water. The residues were filtered through Gooch filter crucible, dried at $100^{\circ} \mathrm{C}$ for 2 hours in an oven, cooled and washed. The percentage crude fibre in the rice sample was calculated as per the formula:

\section{$\%$ Crude fibre}

$=\frac{\text { weight after drying }}{\text { weight of original sample }} \times 100$ .10

\section{Determination of fat}

Total fat in the rice sample was determined using Soxhlet extraction for $4 \mathrm{hr}$ starting with methanol and ethanol, respectively. About 250 $\mathrm{ml}$ clean boiling flasks were dried in an oven at $105-110{ }^{\circ} \mathrm{C}$ for about $30 \mathrm{~min}$ and cooled in a dessicator. Approximately, $2.0 \mathrm{~g}$ of samples were weighed accurately into labeled thimbles. The dried boiling flasks were weighed correspondingly and filled with about $300 \mathrm{ml}$ of petroleum ether (boiling point 40 $\left.60{ }^{0} \mathrm{C}\right)$. The extraction thimbles were plugged tightly with cotton wool. After that, the Soxhlet apparatus was assembled and allowed to reflux for $6 \mathrm{hrs}$. The thimble was removed with care and petroleum ether collected from the top container and drained into another container for re-use. After that, the flask was dried at $105-110{ }^{\circ} \mathrm{C}$ for 1 hour when it was almost free of petroleum ether. After drying, it was cooled in a dessicator and weighed. Then, $\%$ fat in the rice sample was computed using the formula below:

$$
\% \text { fat }=\frac{\text { Weight of fat }}{\text { Weight of Sample }} \times 100
$$

\section{Determination of protein}

The crude protein content of the rice samples was determined using the Micro-kjeldahl method of AOAC, which involved protein digestion and distillation. (Oko et al., 2012)

\section{a. Protein digestion}

About $2.0 \mathrm{~g}$ of the rice sample was weighed into a Kjeldahl flask and 4 tablets of Kjeldahl Catalyst were added. This was followed up with the addition of $1.0 \mathrm{~g}$ copper sulphate and a speck of selenium catalyst into the mixture, 
and $25 \mathrm{ml}$ concentrated sulphuric acid was introduced. The whole mixture was subjected to heating in the fume cupboard. The heating was done gently at first and increased with occasional shaking till the solution assumed a green color. The temperature of digester was above $420^{\circ} \mathrm{C}$ for about $30 \mathrm{~min}$. The solution was cooled and black particles showing at the neck of the flask were washed down with distilled water. The solution was re-heated gently at first until the green color disappeared. Then, it was allowed to cool. After cooling, the digest was transferred into a $250 \mathrm{ml}$ volumetric flask with several washings and made up to the mark with distilled water and then distilled using Markham distillation apparatus.

\section{b. Protein distillation}

Before use, the Markham distillation apparatus was steamed through for 15 min after which a $100 \mathrm{ml}$ conical flask containing $5 \mathrm{ml}$ boric acid /indicator was placed under the condenser such that the condenser tip was under the liquid. About $5.0 \mathrm{ml}$ of the digest was pipetted into the body of the apparatus via a small funnel aperture. The digest was washed down with distilled water followed by addition of 50 $\mathrm{ml}$ of $60 \% \mathrm{NaOH}$ solution. The digest in the condenser was steamed through for about 5-1 minutes after which enough ammonium sulphate was collected. The receiving flask was removed and the tip of the condenser washed down into the flask after which the condensed water was removed. The solution in the receiving flask was treated with $0.01 \mathrm{M}$ hydrochloric acid. Also, a blank was run through along with the sample. After titration, the $\%$ nitrogen was calculated using the formulae below:

$\%$ Nitrogen $=\mathrm{V}_{\mathrm{s}}-\mathrm{V}_{\mathrm{B}} \times \mathrm{M}_{\mathrm{acid}} \mathrm{x} 0.01401 \times 100 \mathrm{~W}$ ...................12

where, $\mathrm{V}_{\mathrm{s}}=$ Volume $(\mathrm{ml})$ of acid required to titrate sample;
$\mathrm{V}_{\mathrm{B}}=$ Volume $(\mathrm{ml})$ of acid required to titrate the blank;

$\mathrm{M}_{\text {acid }}=$ Molarity of acid; $\mathrm{W}=\mathrm{Weight}$ of sample (g).

Then, percentage crude protein in the rice sample was calculated from the $\%$ Nitrogen as: $\%$ crude protein $=\% \mathrm{~N}$ x F, where, $\mathrm{F}$ (conversion factor), is equivalent to 6.25.

\section{Determination of carbohydrate}

The total percentage carbohydrate content in the rice sample was determined by the difference method as reported by (Oko A. O., 2012). This method involved adding the total values of crude protein, lipid, crude fibre, moisture and ash constituents of the sample and subtracting it from 100 . The value obtained is the percentage carbohydrate constituent of the sample.

$\%$ carbohydrate $=100-(\%$ moisture $+\%$ crude fibre $+\%$ protein $+\%$ lipid $+\%$ ash). ........13

\section{Energy value}

The determination of the energy values, specifically the heat of combustion, of various foods and excreta forms an important part of many investigations in nutrition. The calorimetric bomb is commonly used for these determinations (Benedict and Edward, 1995).

\section{Determination of calcium}

The calcium of the rice sample were determined using the methods of the AOAC methods were determined by Atomic Absorption Spectrometry. Briefly, about $1.0 \mathrm{~g}$ of the rice sample was first digested with 20 $\mathrm{ml}$ of acid mixture by weighing the sample into digestion flask followed by addition of the $20 \mathrm{ml}$ acid mixture. The digestion flask containing the sample and the digestion acid 
mixture was heated with distilled water to 500 $\mathrm{ml}$ mark. After obtaining the digest, aliquots of the clear digest were used for atomic absorption spectrophotometry using filters that matched the different element. The percentage values were later calculated by multiplying the concentrations by 100 .

\section{Cooking characteristics}

\section{Water uptake ratio}

Two grams of rice samples were cooked in 20 $\mathrm{ml}$ of distilled water for a minimum cooking time in a boiling water bath. After this, the contents were drained and the adhering superficial water present on cooked rice was removed by pressing the samples between filter papers. Cooked rice samples were weighed and the water uptake ratio was calculated (determined as increase in weight of rice samples after cooking) (Rachel Thomas et al., 2013).

Water uptake ratio $=\frac{(\text { Weight of cooked rice })}{(\text { Weight of uncooked rice })}$ ..............14

\section{Grain elongation during cooking}

The length of 10 whole rice kernels after cooking (as above in the volume expansion ratio) was measured by using the micro-scale, and the average kernel length determined. Kernel elongation ratio was calculated by dividing the average length of cooked kernel by the average length of the raw (uncooked) rice (Verma, 2015).

Elongation $=\left(L_{1}-L_{0}\right)$ 15

Where,

$\mathrm{L}_{1}=$ Length of grain after cook

$\mathrm{L}_{0}=$ Length of grain before cook.

\section{Cooking time}

This was determined by boiling $2.0 \mathrm{~g}$ of whole rice kernels from each treatment in $20 \mathrm{ml}$ distilled water, removing different kernels at different time intervals during cooking and pressing between two glass plates until no white core was left. Optimum cooking time was taken (Oko et al., 2012).

\section{Results and Discussion}

\section{Physical properties}

\section{The dimensions and shape}

The dimensions (Length, width, and thickness and L/W ratio) and the shape of the grains were measured and their results were shown in Table 1. The length of the rice samples, under study, was found to be in the range from 5.0 $\mathrm{mm}$ to $7.0 \mathrm{~mm}$ (Indrayani), and $4.9 \mathrm{~mm}$ to $6.0 \mathrm{~mm}(1008)$.

The Average length for Indrayani and 1008 was found to be 6.06 and 5.33 respectively. Similarly the width of the rice samples, was found to be in the range from $1.5 \mathrm{~mm}$ to 2.5 $\mathrm{mm}$ for Indrayani, and $0.9 \mathrm{~mm}$ to $1.5 \mathrm{~mm}$ for 1008 .

The Average width for Indrayani and 1008 was found to be $1.93 \mathrm{~mm}$ and $1.81 \mathrm{~mm}$ respectively. Also the thickness observed in the range of $1.0 \mathrm{~cm}$ to $2.0 \mathrm{~mm}$ for Indrayani and $0.4 \mathrm{~mm}$ to $1.5 \mathrm{~mm}$ for 1008 .

The Average thickness for Indrayani and 1008 was found to be $1.44 \mathrm{~mm}$ and $0.91 \mathrm{~mm}$ respectively. Similarly different investigations have also reported the wide range of grain dimensions while studying with different rice varieties by (Danbaba et al., 2011; S. Kanchana et al., 2012). Whereas lower than those reported by previous investigations for the same correspondingly. 


\section{Equivalent diameter and sphericity}

The equivalent diameter and sphericity for rice of the grains were measured and their results were shown in Table 1 and 2. The Equivalent diameter of Indrayani varies from $1.99 \mathrm{~mm}$ to $3.20 \mathrm{~mm}$, and for 1008 varies from $1.40 \mathrm{~mm}$ to $2.95 \mathrm{~mm}$. The Average equivalent diameter for Indrayani and 1008 was found to be 2.57 $\mathrm{mm}$ and 2.16 respectively.

However the lowest sphericity value was observed in Indrayani $33.61 \%$ and highest $49.09 \%$, in case of 1008 where as the lowest was obtained $27.50 \%$ in same highest $54.09 \%$. The Average sphericities for Indrayani and 1008 were found to be $41.90 \%$ and $32.00 \%$ respectively. Same result found for the equivalent diameter and sphericity for brown rice (Mir et al., 2013).

\section{Aspect ratio}

Determination of aspect ratio distribution is important to classify the grains and determine the extent of off-size in market grade (Varnamkhasti et al., 2008). The aspect ratio for Indrayani was found to be in the range of $0.25-0.40$ and for 1008 in the range of 0.17 0.35 . The Average aspect ratio for Indrayani and 1008 was found to be 0.32 and it is same for both the rice varieties. Where same investigation the mean aspect ratios were found in the range of 0.24 to 0.32 for rice varieties as reported in literature (Mir et al., 2013).

\section{Bulk density and true density}

The bulk density and true density of the grains were measured. In Indrayani rice maximum value of bulk density was found to be $0.93 \mathrm{gm} / \mathrm{cc}$ and minimum $0.91 \mathrm{gm} / \mathrm{cc}$. While in case of 1008 rice, the maximum was observed in $0.91 \mathrm{gm} / \mathrm{cc}$ and minimum $0.89 \mathrm{gm} / \mathrm{cc}$. The average values of bulk density for Indrayani and 1008 rice verities was found to be 0.92 and $0.90 \mathrm{gm} / \mathrm{cc}$ respectively. The respective values for the true densities also were ranged between 1.25 to $1.66 \mathrm{gm} / \mathrm{cc}$ for 1008 and for Indrayani rice were ranged between $1.25 \mathrm{gm} / \mathrm{cc}$ to $1.45 \mathrm{gm} / \mathrm{cc}$. The average values of true density for Indrayani and 1008 rice varities was found to be 1.32 and $1.44 \mathrm{gm} / \mathrm{cc}$ respectively. Similar results were observed to Abida Ali et al., (2013).

\section{Porosity}

The porosity was obtained in the range of 25.60 to $35.86 \%$ in Indrayani rice and 27.20 to $46.39 \%$ in 1008 rice.

Zubairun Usman Bashar et al., (2014) shows that the porosity was obtained in the range of 41.06 to $46.70 \%$ for brown rice cultivars.

\section{Thousand kernel weight}

It was observed that the average weight was found to be 9.51 to $16.10 \mathrm{gm}$ for 1008 and Indrayani respectively. The thousand kernel weight decreased with the level of processing. These values were higher than those observed for rough and white rice varieties (Kanchana et al., 2012; Mir et al., 2013), respectively. The investigation shows the variation in weight according to size and shape.

\section{Angle of repose}

The average value of angle of repose was found to be 32.60 to 32.70 for rice Indrayani $\& 1008$, respectively. The mean values are within the same range as reported rice varieties (Mir et al., 2013).

Angle of repose finds its application in hopper designing which determines the maximum angle of a pile of grain with the horizontal plane, while the hopper wall's inclination angle should be greater than the angle of repose to ensure the continuous flow of the materials by gravity. 
Table.1 Physical parameters for Indrayani rice

\begin{tabular}{|c|c|c|}
\hline Parameters & Indrayani rice & 1008 Rice \\
\hline Length & $\mathbf{6 . 0 6}$ & $\mathbf{5 . 3 3}$ \\
\hline Width & $\mathbf{1 . 9 3}$ & $\mathbf{1 . 8 1}$ \\
\hline Thickness & $\mathbf{1 . 4 4}$ & $\mathbf{0 . 9 1}$ \\
\hline Equivalent Dia & $\mathbf{2 . 5 7}$ & $\mathbf{2 . 1 6}$ \\
\hline Sphericity & $\mathbf{0 . 4 2}$ & $\mathbf{0 . 3 2}$ \\
\hline Aspect Ratio & $\mathbf{0 . 3 2}$ & $\mathbf{0 . 3 2}$ \\
\hline
\end{tabular}

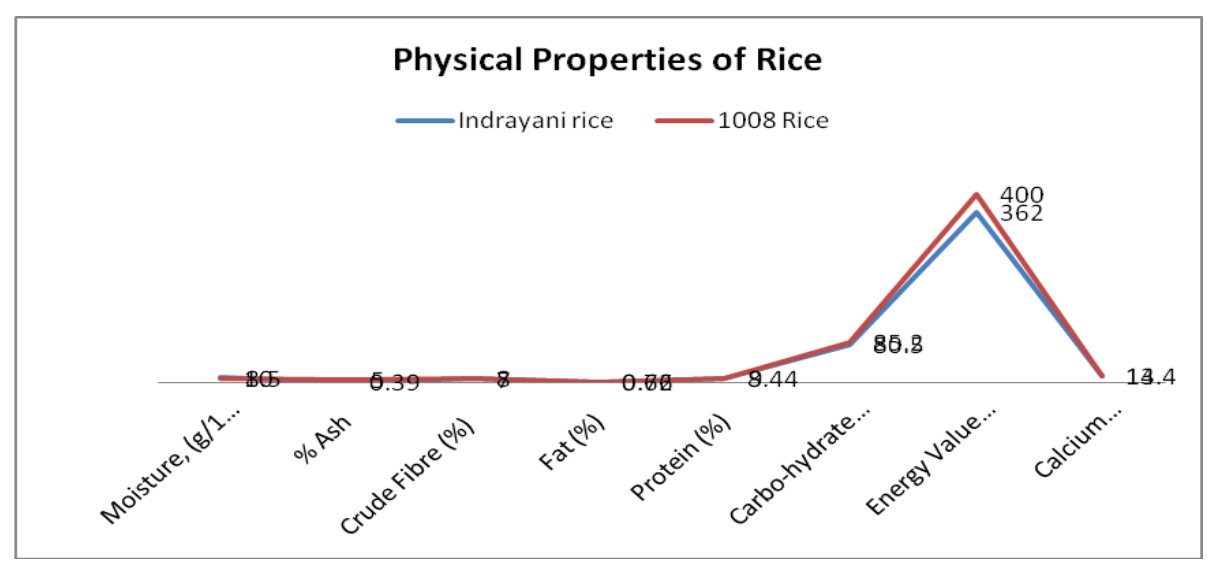

Table.2 Chemical composition of rice

\begin{tabular}{|c|c|c|}
\hline Parameters & Indrayani rice & 1008 Rice \\
\hline Moisture, $(\mathrm{g} / 100 \mathrm{~g})$ & 10 & $\mathbf{8 . 5}$ \\
\hline$\%$ Ash & 0.39 & $\mathbf{5}$ \\
\hline Crude Fibre $(\%)$ & 7 & $\mathbf{8}$ \\
\hline Fat $(\%)$ & 0.66 & $\mathbf{0 . 7 2}$ \\
\hline Protein $(\%)$ & 8.44 & $\mathbf{9}$ \\
\hline Carbo-hydrate $(\%)$ & 80.5 & $\mathbf{8 5 . 2}$ \\
\hline Energy Value $(\mathrm{kcal} / 100 \mathrm{~g})$ & 362 & $\mathbf{4 0 0}$ \\
\hline Calcium $\mathrm{mg} / 100 \mathrm{~g}$ & 13.4 & $\mathbf{1 4}$ \\
\hline
\end{tabular}

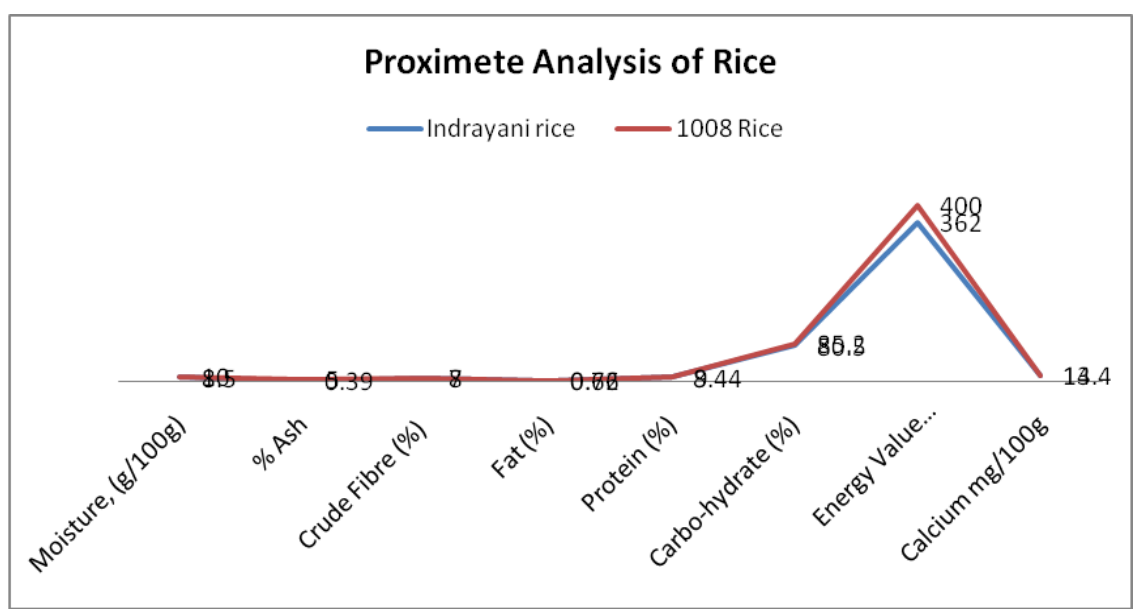




\section{Chemical properties}

\section{Chemical composition}

The result of the proximate composition observed among as shown in Table 2. The moisture content present in the Indrayani and 1008 was found be 10 and $8.5 \mathrm{~g} / 100 \mathrm{~g}$ respectively. The ash present in the Indrayani and 1008 was found be 0.39 and $4.0 \%$ respectively. The crude fibre present in the Indrayani and 1008 was found be 7.0 and $7.1 \%$ respectively. The fat content in Indrayani \& 1008 rice was found to be $0.66 \%$ and $0.62 \%$ respectively. The protein present in the Indrayani and 1008 was found be 8.44 and $8.31 \%$. The carbohydrate content in the rice varieties ranged between $51.50-86.92$ $\%$. The carbohydrate content in the Indrayani was found to be $80.5 \%$ and that for 1008 $82.1 \%$ r. Apart from one of the newly introduced hybrid rice variety " 1108 " which had a normal carbohydrate percentage, virtually all the rice varieties have appreciably high carbohydrate content (Oka et al., 2012).

\section{Energy value and calcium}

The Energy value among the rice varieties studied ranged between 262.94 - 398.82 $\mathrm{kcal} / 100 \mathrm{~g}$ (Oka et al., 2012). The energy value was found to be $362 \mathrm{kcal} / 100 \mathrm{~g}$ and 400 $\mathrm{kcal} / 100 \mathrm{~g}$ for Indrayani and 1008 respectively.

Calcium Content was found to be 13.4 and $14.0 \mathrm{mg} / 100 \mathrm{gm}$ for Indrayani and 1008 respectively. The similar results were observed to Oko (2012).

\section{Cooking characteristics}

\section{Water uptake ratio}

The rice cooking quality characteristics evaluated included water uptake ratio, grain elongation during cooking $(\mathrm{mm})$, optimum cooking time (i.e. normal cooking time plus 2 min). The values for water uptake ratio varied from 1.13-3.35 with a value of Indrayani \& 1008 rice is 3.51 and 3.18 (Oko et al., 2012, Verma et al., 2015). The investigation shows the maximum value 3.50 and minimum value 2.80 .

\section{Grain elongation}

The values of grain elongation during cooking among the varieties studied ranged between $0.108-0.320 \mathrm{~cm}$ (Oko et al., 2012) with a mean value of $0.204 \pm 0.76 \mathrm{~cm}$. It is worthy of note that all the newly introduced hybrid varieties showed very low values for grain elongation. The grain elongation in selected varieties Indrayani and 1008 Rice is $0.122 \mathrm{~cm}$ and $0.118 \mathrm{~cm}$ respectively.

\section{Cooking time}

The optimum cooking time similarly varied significantly among the rice ranging from 8 $12 \mathrm{~min}$ (Oko et al., 2012). "Indrayani rice" took the longest time to cook, \& "1008 rice" took the shortest time interval to cook; and others took average time to cook (Rachel Thomas et al., 2013). Cooking time of Indrayani rice is $11 \mathrm{~min} 36 \mathrm{sec}$, and cooking time of 1008 rice is 9 min $61 \mathrm{sec}$.

In conclusion, the investigation has shows that physical dimension and size related characteristics of 1008 and Indrayani rice vary significantly. The information is useful for optimizing operations, designing the storage structures and machinery, which will help to avoid the postharvest losses and to find the end use of the particular rice.

The chemical result shows that 1008 rice contain high nutritional value than Indrayani. 1008 rice contain more carbohydrate, energy and calcium than Indrayani but have less amount of protein and Fat than Indrayani. 
Based on the results obtained from this study, 1008 was observed to have good cooking and eating characteristics, thus signifying the high demand for the rice. It can also be concluded from the result of grain elongation during cooking, water uptake and cooking time that compared favourably with the checks and therefore, 1008 rice may cook dry, fluffy, less tender which is quality demanded by most consumers, and this may attract premium price for 1008 .

\section{References}

Abida, A., Touseef, A. W., Idrees, A. W., Farooq, A., M., (2016) Comparative study of the physico-chemical properties of rice and corn starches grown in Indian temperate climate. Southi society of Agricultural science; 15: 75-82.

Anugrahati,N.A., Pranoto,Y., Marsono,Y and Marseno, D.W., (2017) Physicochemical properties of rice (Oryza sativa L.) flourand starch of two Indonesian rice varieties differing in amylose content., International Food Research Journal 24(1): 108113.

AOAC. 2003. Official method of analysis of AOAC. Association of analytical chemist (AOAC) International.

Chen,H., Siebenmorgen, T. I., Griffin, K., (1998) Quality characteristics of long grain rice milled in two commercial system., cereal chemistry; 75(4): 560565

Daomukda, N., MoongngarmA., Payakapol, L. and Noisuwan, A., (2011), Effect of Cooking Methods on Physicochemical Properties of Brown Rice. 2nd International Conference on Environmental Science and Technology IPCBEE;

Francies, G. B., and Edward, L. F., (1972) The determination of methods for energy value, protein, carbohydrates, fat.

Haqim, N., Aminath, A. and Anizan, I. (2013) Physicochemical, Vitamin B and Sensory Properties of Rice Obtained by System of Rice Intensification (SRI) Sains Malaysiana 42(11): 16411646.

Itani, T., Tamaki, A., Arai E., and Honio, T., (2002) Distribution of amylase, Nitrogen and Minerals in rice kernel with various characters. Jurnal of Agricultural and food chemistry; 50(19): 5326-5322.

Juliano, B. O., (1972) The rice caryopsis and its composition:, In Houston D. F. (Ed), Rice Chemistry And Technology, Am. ASSOC, Cereal Chemistry, Inc. St. Paul. Minn. 16.

Kataria, R., Proximate Nutritional Evaluation of Maize and Rice - Gluten Free Cereal, (2013). Journal of Nursing and Health Science (IOSR-JNHS); 3(2), PP 01-06.

Khan, S. A., Shinwari Z. K. and Rabbani M. A., (2013), Study of total seed protein pattern of rice (Oryza sativa L.) Pak.J. Bot.; 45(3): 871-876.

Lodh, S. B. 2002. Quality evaluation of rice for domestic and international consumers, In Genetic evaluation and utilization (GEU) in rice improvement, p. 135- 140. CRRI: Cuttack.

Lubna, Taha Mohamed Efbashir, (2005) Physicochemical and cooking quality characteristics of long and short rice.,B.Sc. (Agric.) Honours, University of Al-Zaiem AI-Azhari (2001).

Mir, S. A., Bosco, S. J. D. and Sunooj, K. V., (2013), India Evaluation of physical properties of rice cultivars grown in the temperate region of India. International Food Research Journal, 20(4): 1521-1527. 
Mohammad, J. and Naimeh K., (2014) Some physical properties of rice seed (Oryza sativa), IIOABJ; 3(4); 2012: 15-18.

Mohsenin, N.N. 1986. Physical properties of plants and animals. New york Gordon and Breach.

Muhammad, A, Muhammad, S. H., Iqra, S., Muhammad, A., Amna, A. and Chohan, S. A. (2013), Basmati-Rice a Class Apart A review, JRR, an open access journal; 3(4).

Noomborm, A., Kongserce, N. and Apintanapong, N. (1997), Effect of ageing on the quality of glutanious rice crackers, cereal Chemisrty, 74: 12-15.

Oko A. O.1, Ubi B. E., Dambaba N. (2012), Rice cooking quality and physico chemical characteristics: a comparative analysis of selected local and newly introduced rice varieties in Ebonyi State, Nigeria Food and Public Health, 2(1): 43-49.

Otegbayo, B. O., Osamuel, F. and Fashakin, J. B. 2001. Effect of parboiling on physico-chemical qualities of two local rice varieties in Nigeria. Journal of Food Technology in Africa 6(4): 130-132.

Perdon, A. A., Marks, B. P., Siebenmoryen, T. J. and Reid N. B., (1997), Effect of rough rice storage condition an amylograph and cooking properties of medium grain rice in Bengal. Cereal chemistry, 74: 864-867

Rachel, T., Wan-Nadiah, W. A. and Bhat R.,
(2013), Physiochemical properties, proximate composition, and cooking qualities of locally grown and imported rice varieties marketed in Penang, Malaysia, International Food Research Journal; 20(3): 1345-1351.

Simonelli, C., Abbiati, A. and Cormegna A., (2016),

Physicochemical Characterization of some Italian rice varieties. Rivista di scienza dell' alimentazione, numero 1, gennaio; 45: 09-23.

Suganthi. A and Fathima Nacchair (2015) Quality Parameters of different Varieties of Paddy Rice grown in Vadakkanchery, Kerala. IJAPBC; 4(2), Pp. 2277 - 4688.

Tyagi, A. K., Khurana, J. P., Khurana, P., Raghuvanshi, S., Gaur, A., Kapur, A., Gupta, V., Kumar, D., Ravi, V., Vij, S., Khurana, P. and Sharma, S. 2004. Structural and functional analysis of rice genome. Journal of Genetics 83(1): 79-99.

Varnamkhasti, M.G., Mobli, H., Jafari, A., Keyahani. A.R, Soltanabadi, M.H., Rafiee, S. and Khairalipour, K. 2008. Some physical properties of rough rice (Oriza sativa L.) grain. Journal of cereal Science, 47(3): 496-501.

Verma, D. K., Mohan, M., Prabhakar, P. K. and Srivastav, P. P., (2015), Physicochemical and cooking characteristics of Azad basmati International Food Research Journal; 22(4): 1380-1389.

\section{How to cite this article:}

Priti P. Lad, Rakesh T. Gangurde, Pankaj J. Jadhav, Samadhan L. Gavade and Nitesh A. Pachpor. 2018. A Comparative Study of Physico-chemical and Cooking Qualities of Rice. Int.J.Curr.Microbiol.App.Sci. 7(12): 1560-1570. doi: https://doi.org/10.20546/ijcmas.2018.712.184 